\title{
Relationship of Abundance of Oceanic Sea Skaters, Halobates in the Tropical Pacific Ocean to Surface Biomass and Chlorophyll/Oxygen Concentrations
}

\author{
Takahiro Furuki1, Takero Sekimoto', Noritomo Umamoto1, Mitsuru Nakajo², \\ Chihiro Katagiri ${ }^{3}$, Tetsuo Harada ${ }^{1,4^{*}}$ \\ ${ }^{1}$ Laboratory of Environmental Physiology, Graduate School of Integrated Arts and Sciences, \\ Kochi University, Kochi, Japan \\ ${ }^{2}$ Laboratory of Science Education, Graduate School of Integrated Arts and Sciences, Kochi University, \\ Kochi, Japan \\ ${ }^{3}$ Tokyo Denki University, Tokyo, Japan \\ ${ }^{4}$ Graduate School of Integrated Arts and Sciences, Kochi University, Kochi, Japan \\ Email: "haratets@kochi-u.ac.jp
}

Received 6 February 2016; accepted 21 June 2016; published 24 June 2016

Copyright $@ 2016$ by authors and Scientific Research Publishing Inc.

This work is licensed under the Creative Commons Attribution International License (CC BY).

http://creativecommons.org/licenses/by/4.0/

\section{c) (i) Open Access}

\begin{abstract}
Relationship of population density of oceanic sea skaters collected from tropical and subtropical zones in the Pacific Ocean was examined to chlorophyll concentration/Dissolved Oxygen concentration and biomass in surface sea water. The four parameters shown above were measured at the site of $12^{\circ} \mathrm{N} 135^{\circ} \mathrm{N}$ during the cruise, MR13-03 cruise, and at the site of $25^{\circ} \mathrm{N} 160^{\circ} \mathrm{E}$ during another cruise KH-14-02. Significant and positive correlation between all biomass (especially invertebrates) and population density of oceanic sea skaters collected with a Neuston-Net trailing during 15 min was shown in overall analysis on the data of the both samplings $(p<0.001)$. Moreover, dissolved oxygen was much lower at $25^{\circ} \mathrm{N} 160^{\circ} \mathrm{E}$ than that at $12^{\circ} \mathrm{N} 135^{\circ} \mathrm{N}$ with similar value of chlorophyll value $(p<0.001)$. These results would suggest that more food resource would be available at $25^{\circ} \mathrm{N} 160^{\circ} \mathrm{E}$ than that at $12^{\circ} \mathrm{N} 135^{\circ} \mathrm{N}$ for keeping high density population of oceanic sea skaters.
\end{abstract}

\section{Keywords}

Oceanic Sea Skaters, Chlorophyll Concentration/Dissolved Oxygen Concentration,

*Corresponding author.

How to cite this paper: Furuki, T., Sekimoto, T., Umamoto, N., Nakajo, M., Katagiri, C. and Harada, T. (2016) Relationship of Abundance of Oceanic Sea Skaters, Halobates in the Tropical Pacific Ocean to Surface Biomass and Chlorophyll/Oxygen Concentrations. Natural Science, 8, 264-270. http://dx.doi.org/10.4236/ns.2016.86031 


\section{Biomass in the Neuston Net}

\section{Introduction}

Oceanic sea skaters inhabiting tropical and temperature Pacific Ocean

Marine insects have been thought to consist of a few thousand species, and most of them belong to the Coleoptera, Hemiptera and Diptera orders inhabiting various marine environments [1]. However, the insects which inhabit open ocean have been known to be only five species of the oceanic sea skaters as the five species of the genus Halobates [2]. Recently, another coastal species, H. princeps has been reported to have "open ocean population” in the tropical Pacific Ocean [3]. In the tropical to temperature Pacific Ocean, three species of Halobates, H. micans, H. germanus and H. sericeus are dominant [2] [4] [5]. However, these three species could be seen to inhabit the roughly separated "main-area" there: H. micas with biggest body size inhabiting mainly "open" area around equators $\left(15^{\circ} \mathrm{N}-15^{\circ} \mathrm{S}\right), H$. germanus with middle body size inhabiting the area "near to the islands" of $15^{\circ} \mathrm{N}-15^{\circ} \mathrm{S}$ and $H$. sericeus with smallest body size inhabiting the northern and southern area $\left(15^{\circ} \mathrm{N}\right.$ $\left.40^{\circ} \mathrm{N}, 15^{\circ} \mathrm{S}-30^{\circ} \mathrm{S}\right)$ [2] [5] [6].

The combined data of chlorophyll concentration and dissolved oxygen concentration (DO) as an indicator of population density of the oceanic sea skaters.

A clear positive correlation was shown between the population density of $H$. micans and the combination of "higher chlorophyll concentration" plus "lower dissolved oxygen concentration" in the tropical Indian Ocean suggesting the higher biomass as food resources for the oceanic sea skaters [7]. This relationship would mean that the combination of "higher" chlorophyll concentration and "lower" dissolved oxygen concentration as the indicator of higher population density of the oceanic Halobates. However, such clear positive correlation has been shown by only one occasion in the Indian Ocean. Moreover, there has been no example of direct analysis between the Halobates population density and sea surface biomass as food resources for the oceanic sea skaters.

This study aims, first, to clarify whether this combined data of higher chlorophyll and lower DO mean an indicator of higher population density of the oceanic sea skaters also in the Pacific Ocean population, and second, to investigate the direct relationship between the population density of the oceanic sea skaters and the biomass in the surface water as the food resources for the sea skaters.

\section{Materials and Methods}

\subsection{Samplings by the Neuston Net during the Cruises}

During the two cruises: Cruises No.: MR13-03 by R/V MIRAI [8687t] and cruise No.: KH-14-02 by R/V HAKUHOMARU [3991t], both owned by JAMSTEC [Japan Agency of Marine-earth Science and Technology], samplings were performed in the dark with a Neuston net (an open box-typed frame and inner net with a $1.3 \mathrm{~m}$ wide opening and $6 \mathrm{~m}$ length of the net), between $1900 \mathrm{~h}$ and $0100 \mathrm{~h}$. The net was towed for $15 \mathrm{~min}$ each time at the starboard side. Towing was repeated 2 times at each station with the ship cruising at a speed of 2 knots. During the MR13-03 cruise, three toes of Neuston net at one night were performed at a station located at $24^{\circ} \mathrm{N}$ $138^{\circ} \mathrm{E}$, and 15 stations located at $12^{\circ} \mathrm{N} 135^{\circ} \mathrm{E}$. The Neuston net was trailed for the 3 consecutive samplings (each $15 \mathrm{~mm} \times 3$ times) on the sea surface to allow us to rescue living sea skaters from the bottom of the net for use in cool coma experiments [8]. The surface area swept by the nets is expressed as a value of the flow meter $\mathrm{x}$ the front width of the nets.

\subsection{Measurements of Chlorophyll Contents and Dissolved Oxygen (DO) during the Two Cruises of MR13-03 and KH-14-02}

During the cruise, MR13-03, surface water sensor system was put at the bottom of the research vessel (R/V) MIRAI and consists of sensors to measure water temperatures, conductivity (salinity concentration), chlorophyll contents (can be measured by a fluorescence spectrometer) and dissolved oxygen continuously during the cruise. During the cruise, KH14-02, CTD casting was performed at all the sampling points. The cast was performed to use the Amado-cable more than $500 \mathrm{~m}$ long and to measure the conductivity, water temperature, depth, dissolved 
oxygen and chlorophyll contents continuously through water surface to $500 \mathrm{~m}$ in the depth. Data of dissolved oxygen and chlorophyll at $5 \mathrm{~m}$ depth were used for the analysis.

\section{Results}

\subsection{Distribution of Oceanic Sea Skaters in Tropical and Subtropical Areas of the Western Pacific Ocean}

As shown in Table 1, Halobates sericeus mostly exclusively dominated the latitude area of $24^{\circ} \mathrm{N}-25^{\circ} \mathrm{N}$ in the western sub-tropical Pacific Ocean with a relatively high population density of more than 50,000 insects per $\mathrm{km}^{2}$. On the other hand, H. micans and $H$. germanus dominated the lower latitude area of $12^{\circ} \mathrm{N}$. These data match those of other reports by Andersen and Cheng [2] and Harada et al. [5].

\subsection{Relationship between Population Density and Biomass Collected by Neuston Net}

Analysis of the relationship between the population density of oceanic sea skaters and all biomass collected by the Neuston net trailing (Pearson's test: $r=0.605, p<0.001$ ) showed significant and positive correlation (Figure 1). Significant positive correlation was also shown between the population density of oceanic sea skaters and biomass excluding fishes (mostly invertebrates like as jelly fishes and copepods) (Figure 2). However, there was no correlation between the population density and fish biomass (Figure 3).

\subsection{Relationship between Population Density and Chlorophyll and Dissolved Oxygen Concentration}

The relationship between the dissolved oxygen concentration and chlorophyll concentration in the surface water was shown in Figure 4. The oxygen concentration in the areas at $24^{\circ} \mathrm{N} 160^{\circ} \mathrm{E}$ were much lower than that in

Table 1. (a) Population density of oceanic sea skaters, Halobates among two areas of open Pacific Oceans. Samplings were performed during the cruise, MR-13-03. H.m.: Halobates micans; H.g.: H. germanus; H.s.: H. seriseus; H.p.: H. princeps; sp.: H. sp.: Density: individual number $/ \mathrm{km}^{2}$; (b) Population density of oceanic seaskaters, Halobates among two areas of open Pacific Oceans. Samplings were performed during the cruise, KH-14-02. H.m.: Halobates micans; H.g.: H. germanus; H.s.: H. seriseus; H.p.: H. princeps; sp.: H. sp.: Density: individual number $/ \mathrm{km}^{2}$.

\begin{tabular}{|c|c|c|c|c|c|c|c|}
\hline \multirow{3}{*}{$\begin{array}{c}\text { A. } \\
24^{\circ} 00^{\prime} \mathrm{N} 138^{\circ} 10^{\prime} \mathrm{E} \\
(\text { Station } 1)\end{array}$} & \multicolumn{7}{|c|}{ (a) MR-13-03: Western Subtropical and Tropical Pacific Ocean } \\
\hline & \multicolumn{2}{|c|}{ Total } & \multirow[t]{2}{*}{$\mathrm{Hm}$} & \multirow[t]{2}{*}{$\mathrm{Hg}$} & \multirow[t]{2}{*}{ Hs } & \multirow[t]{2}{*}{ Hp or sp } & \multirow[t]{2}{*}{$\mathrm{AS}^{\#}$} \\
\hline & Females & Males & & & & & \\
\hline Number & 179 & 126 & 6 & 0 & 299 & 0 & 0031594 \\
\hline Density & 56656.5 & 39881.1 & 1899.1 & 0 & 94638.5 & 0 & - \\
\hline \multirow{2}{*}{$\begin{array}{c}\text { B. } \\
12^{\circ} 00^{\prime} \mathrm{N} 135^{\circ} 00^{\prime} \mathrm{E} \\
(\text { Stations } 2-10)\end{array}$} & \multicolumn{2}{|c|}{ Total } & H.m & H.g & H.s & H.p or sp & $\mathrm{AS}^{\#}$ \\
\hline & Females & Males & & & & & \\
\hline Number & 484 & 119 & 276 & 327 & 0 & 0 & 0.02802519 \\
\hline Density & 17270.2 & 4246.2 & 9848.3 & 11688.1 & 0 & 0 & - \\
\hline \multirow{3}{*}{$\begin{array}{l}\text { A. Northern } \\
\text { Station at } \\
47^{\circ} 00^{\prime} \mathrm{N} 160^{\circ} 00^{\prime} \mathrm{N}\end{array}$} & \multicolumn{7}{|c|}{ (b) KH-14-02 (This cruise; Stations A and B): Western Subtropical and Tropical Pacific Ocean } \\
\hline & \multicolumn{2}{|c|}{ Total } & H.m. & $\mathrm{Hg}$ & Hs & $H p$ or sp & $\mathrm{AS}^{\#}$ \\
\hline & Females & Males & & & & & \\
\hline Number & 0 & 0 & 0 & 0 & 0 & 0 & 0 \\
\hline Density & 0 & 0 & 0 & 0 & 0 & 0 & 0 \\
\hline \multirow{2}{*}{$\begin{array}{c}\text { B: } \\
\text { Southern Station at } \\
25^{\circ} 00^{\prime} \mathrm{N} 160^{\circ} 00^{\prime} \mathrm{E}\end{array}$} & \multicolumn{2}{|c|}{ Total } & $\mathrm{Hm}$ & $\mathrm{Hg}$ & Hs & $H p$ or sp & $\mathrm{AS}^{\#}$ \\
\hline & Female & Males & & & & & \\
\hline Number & 593 & 254 & 0 & 0 & 847 & 0 & 0.0162708 \\
\hline Density & 36445.7 & 15610.8 & 0 & 0 & 52056.4 & 0 & - \\
\hline
\end{tabular}




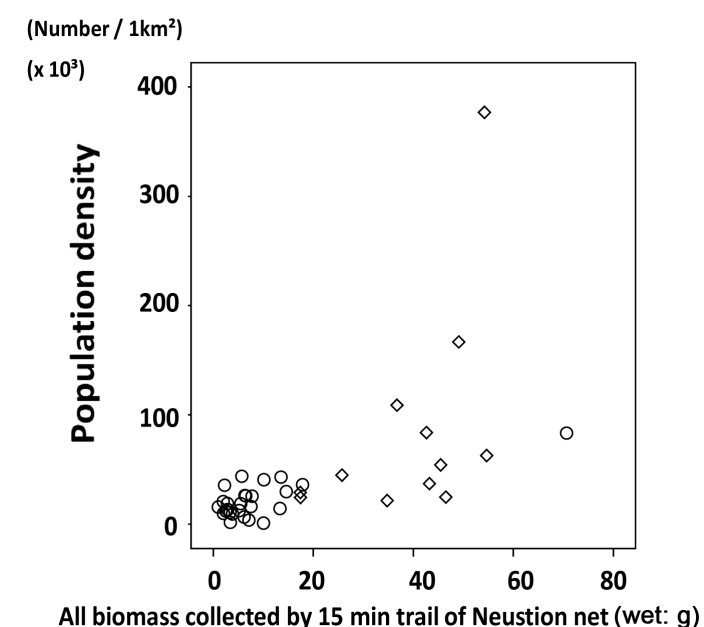

Figure 1. Positive correlation shown between population density of oceanic sea skater and all biomass collected by the Neuston net Trailing (Pearson's test: $\mathrm{r}=0.605, p<0.001$ ). Circles: MR13-03; Squares: KH14-02.

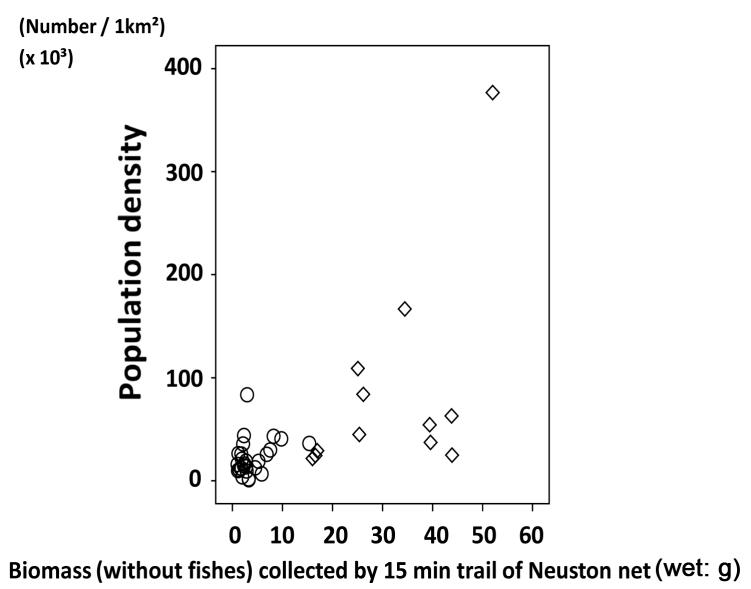

Figure 2. Positive correlation shown between population density of oceanic sea skater and all biomass (excluding fishes) collected by the Neuston net trailing (Pearson's correlation analysis, $\mathrm{r}=0.633, p<0.001$ ). Circles: MR13-03; Squares: KH14-02.

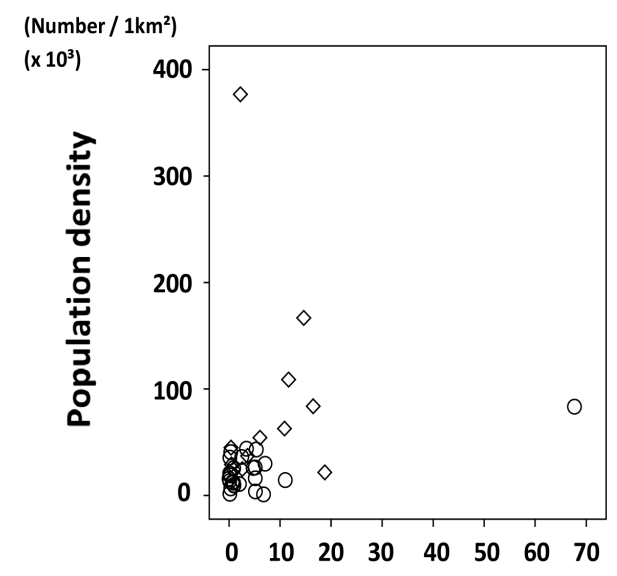

Fish biomass collected by 15 min trail of Neuston net (wet: $\mathrm{g}$ )

Figure 3. No positive correlation shown between population density of oceanic sea skater and all fishes collected by the Neuston net trailing (Pearson's correlation analysis, $\mathrm{r}=0.196, p=0.233$ ). Circles: MR13-03; Squares: KH14-02. 


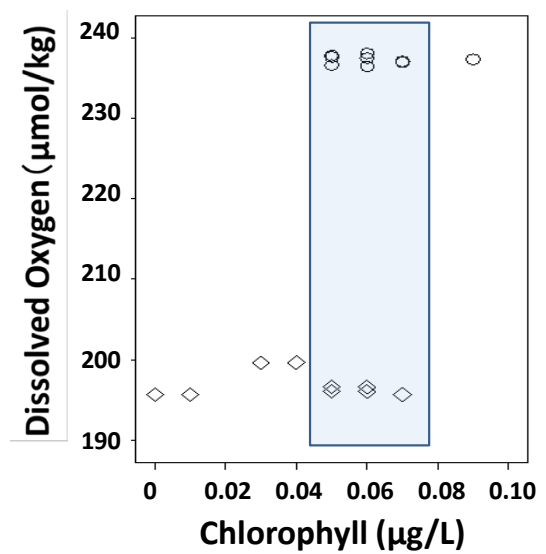

Figure 4. Relationship between dissolved oxygen and chlorophyll in the surface sea water due to CTD casting. Light blue square shows the big difference in dissolved oxygen between MR13-03 with lower population density and KH14-02 with higher population density. The average value of dissolved oxygen was $196.22( \pm 0.38 \mathrm{micro}-\mathrm{mol} / \mathrm{kg})$ in the surface with at $25^{\circ} \mathrm{N} 160^{\circ} \mathrm{E}\left(\mathrm{KH}-14-02\right.$ : diamonds) and significantly much lower than $238.3( \pm 0.55)$ at $12^{\circ} \mathrm{N} 135^{\circ} \mathrm{E}$ (MR13-03: circles) (Mann-Whitney U-test: $\mathrm{z}=-3.985, p<0.001$ ).

those at $12^{\circ} \mathrm{N} 135^{\circ} \mathrm{E}$, although the range of the chlorophyll concentration in the areas at $24^{\circ} \mathrm{N} 160^{\circ} \mathrm{E}$ was greatly overlapped with that in the areas at $12^{\circ} \mathrm{N} 135^{\circ} \mathrm{E}$. In the common chlorophyll value range of $0.05-0.70$ microgram/L, the population density of sea skaters collected at "lower" oxygen dissolved area $\left(24^{\circ} \mathrm{N} 160^{\circ} \mathrm{E}\right)$ was significantly higher than that collected at "higher" oxygen area $\left(12^{\circ} \mathrm{N} 135^{\circ} \mathrm{E}\right)$ (Figure 4 and Figure 5).

\section{Discussion}

\subsection{Distribution of Oceanic Sea Skaters in Tropical and Subtropical Areas of the Western Pacific Ocean}

Andersen and Cheng [2] showed the distributions of the three species of oceanic sea skaters inhabiting Pacific Ocean were roughly separated: the biggest species, Halobates micans was distributed mainly open area around the equator in the latitudes of $15^{\circ} \mathrm{N}$ to $15^{\circ} \mathrm{S}$, the middle sized species $H$. germanus was mainly near to the islands in the latitudes of $20^{\circ} \mathrm{N}$ to $20^{\circ} \mathrm{S}$, and the smallest species $\mathrm{H}$. sericeus was mainly distributed to the northern area of $15^{\circ} \mathrm{N}-40^{\circ} \mathrm{N}$. The results of this study match the previous knowledge that $H$. germanus and $H$. micans were dominant at $12^{\circ} \mathrm{N} 135^{\circ} \mathrm{E}$ and the $H$. sericeus was dominant at $24^{\circ} \mathrm{N} 138^{\circ} \mathrm{E}$ and $25^{\circ} \mathrm{N} 160^{\circ} \mathrm{E}$. The critical line for the dominant occupation by the bigger two species or smallest species could be located between $12^{\circ} \mathrm{N}$ and $24^{\circ} \mathrm{N}$ in the Pacific Ocean. What is the mechanism of the separated distribution? It could be speculated that the difference in the temperature preference (the smallest species prefers lower temperature area: Nakajo et al. [6], Furuki et al., [8]) would lead to the higher latitude difference in the distribution. Another hypothesis could be cannibalism: adults of $H$. micans are very active to do cannibalism into the smaller species based on the accumulated observations during the rearing sea skaters during several cruises (Harada, unpublished).

\subsection{Relationship between Population Density and Biomass Collected by Neuston Net}

A clear positive correlation was seen between the abundance of individuals and the whole biomass or biomass excluding fishes collected by the Neuston net in this study. This would mean that the main foods for the oceanic sea skaters could be speculated to be not the dead bodies of fishes but zooplanktons. Cheng [9] reviewed that one experiment ensured the simulation of the relative composition of several kinds of atoms in the liquid inside the stomach of oceanic sea skaters into another composition of atoms of zooplanktons. This study matches this report that zooplanktons could be major of the foods of the oceanic sea skaters.

\subsection{Relationship between Population Density and Chlorophyll and Dissolved Oxygen Concentrations}

The sampling areas at $25^{\circ} \mathrm{N} 160^{\circ} \mathrm{E}$ and at $12^{\circ} \mathrm{N} 135^{\circ} \mathrm{E}$ had common areas showing the surface water chlorophyll 


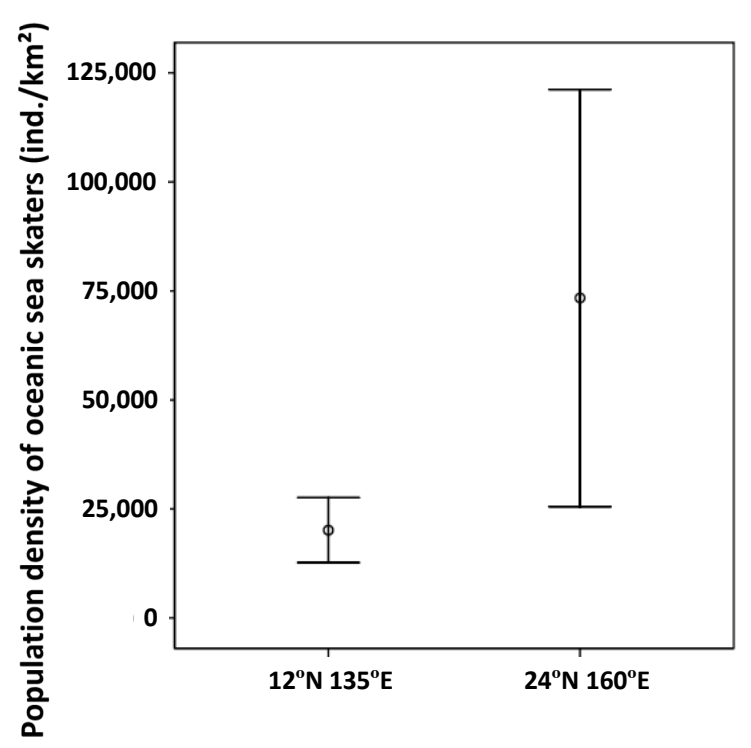

Figure 5. Comparison of population density of oceanic sea skaters at $12 \mathrm{~N} 135 \mathrm{E}$ to that at $24 \mathrm{~N} 160 \mathrm{E}$. Sampling stations were limited to the sites where surface chlorophyll value was common and ranged $0.05-0.07$ micro-gram/L (range shown by blue square in Figure 4). (Mann-Whitney U-test: $\mathrm{z}=-3.212, p=0.001$ ).

value of $0.05-0.07$ microgram/L. In the common areas, the area of $25^{\circ} \mathrm{N} 160^{\circ} \mathrm{E}$ showed higher sea skater population and lower dissolved oxygen value than the area of $12^{\circ} \mathrm{N} 135^{\circ} \mathrm{E}$. This relationship would mean that the area of $25^{\circ} \mathrm{N} 160^{\circ} \mathrm{E}$ could be speculated to have more zooplanktons as foods of oceanic sea skaters than the area of $12^{\circ} \mathrm{N} 135^{\circ} \mathrm{E}$. The clear positive correlation was shown between the population density of $\mathrm{H}$. micans and the combination of "higher chlorophyll concentration" plus "lower dissolved oxygen concentration" in the tropical Indian Ocean suggesting the higher biomass as food resources for the oceanic sea skaters [7]. This relationship would mean that the combination of "higher" chlorophyll concentration and "lower" dissolved oxygen concentration means the indicator of higher population density of the oceanic Halobates. Such clear relationship was also shown by tropical and subtropical populations in the Pacific Ocean. Moreover, direct and positive relationship is shown by this study between the Halobates population density and sea surface biomass as food resources for the oceanic sea skaters as something new to science.

\section{Acknowledgements}

We would like to thank Prof. K. KOGURE (Chief Scientist of the cruise: KH-14-02, Professor, The University of Tokyo) and Dr. M. KATSUMATA (Head Scientist of the cruise: MR-13-03) for their permissions of doing this study during the cruises on the R/V HAKUHOMARU and R/V MIRAI, for their warm suggestions on this study, and encouragements and helps throughout these cruises. The samplings and the experimental study were also possible due to supports from all of the crew (Captain of KH-14-02: Mr. T. SEINO and Captain of MR13-03: Mr. Y. TSUTSUMI) and all the scientists and the engineers from GODI and MWJ in these cruises. We would like to give special thanks to them.

\section{References}

[1] Cheng, L. and Frank, J.H. (1993) Marine Insects and Their Reproduction. Oceanography and Marine Biology, 31, 479506.

[2] Andersen, N.M. and Cheng, L. (2004) The Marine Insect Halobates (Heteroptera: Gerridae): Biology, Adaptations Distribution, and Phylogeny. Oceanography and Marine Biolology, 42, 119-180.

[3] Harada, T., Takenaka, S., Sekimoto, T., Nakajo, M., Inoue, T., Ishibashi, T. and Katagiri, C. (2011) Heat Coma as an Indicator of Resistance to Environmental Stress and Its Relationship to Ocean Dynamics in the Sea Skaters, Halobates (Heteroptera: Gerridae). Insect Science, 18, 703-711. http://dx.doi.org/10.1111/j.1744-7917.2011.01409.X

[4] Ikawa, T., Okabe, H., Hoshizaki, S., Kamikado T. and Cheng, L. (2004) Distribution of the Oceanic Insects Halobates (Hemiptera: Gerridae) off the South Coast of Japan. Entomological Science, 7, 351-357. 
http://dx.doi.org/10.1111/j.1479-8298.2004.00083.x

[5] Harada, T., Sekimoto, T., Iyota,K. , Shiraki, T., Takenaka, S., Nakajo, M. , Osumi Y. and Katagiri, C. (2010) Comparison of the Population Density of Oceanic Sea Skater of Halobates (Heteroptera: Gerridae) among Several Areas in the Tropical Pacific Ocean and the Tropical Indian Ocean. Formosan Entomologist, 30, 307-316.

[6] Nakajo, M., Sekimoto, T., Emi, K., Ide, R., Wada, K., Inoue, T., Moku, M., Kostal, V., Katagiri, C. and Harada, T. (2013) Comparison of Temperature Preference for Habitat among Three Species of Oceanic Sea Skaters, Halobates micans, H. germanus and H. sericeus. Natural Science, 5, 9-15. http://dx.doi.org/10.4236/ns.2013.512A002

[7] Harada, T., Osumi, Y., Shiraki, T., Kobayashi, A., Sekimoto, T., Nakajo, M., Takeuchi, H. and Iyota, K. (2014) Abundance of Oceanic Sea Skaters, Halobates in the Tropical Indian Ocean with Respect to Surface Chlorophyll and Oxygen Concentrations. Journal of Experimental Marine Biology and Ecology, 460, 32-36. http://dx.doi.org/10.1016/j.jembe.2014.05.025

[8] Furuki, T., Umamoto, N., Nakajo, M., Sekimoto, T., Moku, M., Katagiri, C. and Harada, T. (2015) Comparative Study of Cool Coma Temperature between Two Populations of Oceanic Sea Skaters, Halobates sericeus (Heteroptera: Gerridae), Located at 24-25N and 138E or 160E in the Pacific Ocean. Trends in Entomology, 11, 55-61.

[9] Cheng, L. (1985) Biology of Halobates (Heteroptera: Gerridae). Annual Review of Entomology, 30, 111-135. http://dx.doi.org/10.1146/annurev.en.30.010185.000551

\section{Submit or recommend next manuscript to SCIRP and we will provide best service for you:}

Accepting pre-submission inquiries through Email, Facebook, Linkedin, Twitter, etc A wide selection of journals (inclusive of 9 subjects, more than 200 journals)

Providing a 24-hour high-quality service

User-friendly online submission system

Fair and swift peer-review system

Efficient typesetting and proofreading procedure

Display of the result of downloads and visits, as well as the number of cited articles

Maximum dissemination of your research work

Submit your manuscript at: http://papersubmission.scirp.org/ 